\title{
Does Facebook Reduce Unemployment? A Holistic Research on How Beauty Index Affectsa Facebooker's Chance of Getting Jobs
}

\author{
ANM Moinul Islam ${ }^{1}$ \\ Department of EconomicsAsian University for WomenChittagong, Bangladesh \\ Tram Thi Bich PhamAsian University for Women
}

\begin{abstract}
Facebook, a familiar term, has yet to receive much attention from researchers, social scientists and economists. However, Facebook's power in transmitting information and expanding networks has long been confirmed. Once again, the parallel between the rapid increase in facebooking and decrease in unemployment among Vietnamese youth in the current year is appealing, and it triggers the interest for this study. This paper aims to analyze how personal characteristics and Facebook's features influence users' probability of getting jobs on Facebook. The study investigates the factors influencing the chances of getting jobs on Facebook, based on 400 survey questionnaires. The results show that Beauty Index and membership of job groups overweigh the importance of age, education, marital status and years of using Facebook in influencing an individual's chance of being employed and self-employed on Facebook. The study also opens new scopes for future research about the importance of expertise and searching intensity in getting a job on Facebook.
\end{abstract}

Keywords: Facebook, unemployment, employed, Beauty Index, Vietnam

\section{INTRODUCTION}

After eleven years of its existence - since $4^{\text {th }}$ February 2004 - Facebook succeeds in attracting more than one billion monthly active users worldwide in the $31^{\text {st }}$ December 2014 ("Investor Relations"). On the average, 890 million people are actively using Facebook on a daily basis, which leads to an increase in Facebook's revenue from \$7,872 million to \$12,466 million between 2013 and 2014 ("Investor Relations").Each minute, Facebook has 510 comments and 293,000 statuses posted and 136,000 photos uploaded ("Top 20 Valuable Facebook Statistics").Facebookproves itself to be an effective tool to diffusediverse information, if not the most effective one.Hence, different people depend on Facebook to search for jobs; employers also exploit Facebook to post numerous recruiting advertisements. Additionally, Facebook is a place to build connections. 50\% of all Facebook users have more than 200 friends ("Facebook").Given Facebook's popularity and power in information transmission, it is surprising to realize that there have been only few studies about Facebook's impact on unemployment.

Another reason triggers this research interest is the parallel in the rapid decrease of unemployment and increase in Facebook users in Vietnam. International Labor Force statistics shows weaker employment growth in Southeast Asia, e.g. in Thailand, Laos, Philippines and Korea. In comparison with this situation, the Vietnamese economy is working enormously to create more jobs to meet this challenge, where labor force growth is very swift and is ranked eleventh in the world (World Bank 2013). A remarkable change in rate of unemployment, from $3.2 \%$ in 2012 to $1.3 \%$ in 2013, has been observed in Vietnam (World Bank 2013). At the same time, the number of Vietnamese Internet users increased from 74 million to 128 million between 2011 and 2012, among them about 11 million subscribed to Facebook in 2012 (internewworldstats.com). These statistics cannot be a coincidence. Therefore, based on the assumption of Facebook's influence on unemployment, this study is designed to test the role of Facebook in case of Vietnam's noteworthy reduction in unemployment, particularly in the southern region, where most of the youth use this social network for entertainment and exchange of information. Following, section II of the paper will present literature reviews in the related fields. Section III outlines the research's methodology. Section IV analyzes the Data and section V gives the conclusions along with some limitations.

\section{I.A. Definition of recruiting-process on Facebook}

\footnotetext{
${ }^{1}$ Corresponding Author: ANM Moinul Islam, Ph.D, Associate Professor, Department of Economics, Asian University for Women, Chittagong, Bangladesh. Phone: 880-31-2854980, Cell: 8801815092518, Fax: 880-312854988 Email: moinul.islam@auw.edu.bd 
"First come, first serve" jobs: for jobs that are urgent and require a large amount of labors, facebookers just need to leave their names and phone numbers on job advertisements. Employees will be contacted or receive messages mentioning the locations and responsibilities of the jobs. They can start the jobs immediately, in case the employers and employees agree with all of the conditions.

"Traditional job search process:" job information is also publicly advertised in Facebook's groups. However, these jobs' selection is based on traditional procedure, where applicants need to submit their CVs and cover letters. In this case, Facebook plays a role of job-posting sites such as Indeed or Idealist.

\section{LITERATURE REVIEW}

Studies about impacts of the Internet and social media such as Twitter's or Facebook'son macroeconomic dataare mushroomed. For instance, in January 2015, Facebook, together with its partner Deloitte, published a report on Facebook's global economic impact. According to the report, Facebook indeed triggers the development of the global economy by "connecting people and businesses, lowering barriers to marketing, and stimulating innovation" (1). Facebook becomes a marketing platform connecting customers and sellers; it is also a fruitful destination for app developers, and it is also the reason for the increase in sale of mobile devices and Internet connection ("Facebook's Global Economic Impact,"4). However, the influence of Facebook on unemployment at the local level seems yet to be addressed.It is also worthy to look at what has been done in case of the Internet as references. Kuhn and Skuterud (2004)are pioneer in exploring the Internet's impact on unemployment. They observe that those searching for jobs on the Internet have shorter unemployment duration and spend less time being unemployed. However, when the participants' observable characteristics -age, education and occupation - are held constant, there is no correlation between these two, or in some cases the reverse happens. They then conclude that "either Internet job search is ineffective in reducing unemployment durations, or Internet job searchers are negatively selected on the unobservables." Moreover, a study shows that the website Craigslist has no correlation with unemployment, and it also does not crowd out low-skilled workers. The authors present some explanations. Firstly, there may be many more popular job websites, so Craigslist itself cannot contribute a big effect to unemployment. Another reason may be that online posts do not improve the diffusion of the job information because most of the job information is transferred through interviews. The last reason may be because the study cannot detect the website's impact (Kroft and Pope, 2012: 24).

Besides, many studies show the negative impact of the Internet on unemployment rate. David H. Autor (2001) mentions that online job search leads to some unavoidable problems such as the adverse selection of applicants. Autor argues when the information of jobs is very cheap and easily to get access, employees will simultaneously apply more than one job. This is problematic for employers because they have to screen everyone's application, which increases the cost of recruitment.

On the other side, Constantin Mang argues in his study that the Internet enhances the matching quality between employers and employees (Mang, 2012: 4). The result shows that online job seekers are six percent more likely to apply their skills in their jobs; significantly happier; eight percent more likely to be promoted and receive better social benefits than their counterparts (Mang,2012: 6).

Addition to transmitting job information, the Internet(and Facebook)also promotes online shopping. Statistics reveal that in 2008 more than $85 \%$ of Internet users purchase products online, which is $40 \%$ higher than in 2006 (Prompongstorn et al.,736). In Vietnam, specifically, about 6 out of 10 Vietnamese Internet-users purchase online products. Today, this number increased by about 53\%, compared with the statistics in 2013. Moreover, each online shopper spent $\$ 145$ on the average in 2014 on big branches such as Lazada, Sendo or eBay ("Online Shopping"). Online shopping is gradually replacing traditional forms due to its reduction in "land costs, labor, [and] management" (Ngo, 389).

In conclusion, existing literature examine the Internet's influence on unemployment through analyzing the unemployment duration, the matching quality and the development of online shopping. However, these findings are still puzzling. In the next sections, this paper will utilize these factors to develop a model analyzing Facebook's impact on unemployment in the Vietnamese context.

\section{DATA AND METHODOLOGY}

Data are collected through a survey. Of 400 anonymous participants in this survey majority are students. They are contacted through snowball method. Others were approached directly in job-searching groups. This study employs logistic model to predict the probability of finding a job of a Facebook's user. The model takes into account demographic information as well as Facebook's related features such as the number of friends, followers, or years using Facebook.

$\operatorname{logit}(\pi)=\log \left(\frac{\pi}{1-\pi}\right)=\beta_{0}+\beta_{1} X_{1}+\beta_{2} X_{2}+\beta_{3} X_{3}+\beta_{4} X_{4}+\beta_{5} X_{5}+\beta_{6} X_{6}+\beta_{7} X_{7}+\varepsilon$

Here, 
$\operatorname{logit}(\pi)=$ is the probability a person can get a job on Facebook $(0=$ no, $1=$ yes $)$

$\mathrm{X}_{1}=$ whether the person is beautiful or not $(0=$ no, $1=$ yes $), X_{2}=$ gender of the person $(0=$ male, $1=$ female $), X_{3}=$ age of the person (years), $X_{4}=$ education of the person $(0=$ high-school, $1=$ undergrad, $2=\operatorname{grad}), X_{5}=$ the marital status of the person $(0=$ single, $1=$ married $), X_{6}=$ the number of years the person have used Facebook (years), $\mathrm{X}_{7}=$ the kind of job the person is seeking $(0=$ part-time, $1=$ full-time $)$ and $\varepsilon=$ the stochastic term

\section{III.A. BEAUTY INDEX}

One of the variables for the above model is very intangible and subjective: beauty. This study, however, tries to quantify the beauty index (BI). BI in the average of the numbers of friends, the numbers of followers, and the average number of "likes" one person usually receives for his or her profile pictures on Facebook.

\section{RESULTS AND DISCUSSION}

The mean age of the participants is $20.94( \pm 2.93)$. Among 379 participants revealing their gender, $40 \%$ $(n=153)$ are males; $59 \%(n=225)$ are females and one chose "other."Their educational status is followed: $10 \%$ is pursuing high school level; $2 \%$ is pursing vocational education; $13 \%$ college; $72 \%$ university level and $3 \%$ postgraduate level. Among 287 job seekers on Facebook, 146 of them report to get jobs, either part-time or fulltime or both. On the other hand, 118 of them were or are selling products on Facebook.Job is defined as (1) being employed through Facebook and (2) becoming self-employed by selling products through Facebook .

Table 1:

\begin{tabular}{|c|c|c|c|}
\hline & \multicolumn{3}{|l|}{ Dependent variable: JOB } \\
\hline & Independent variables & Coefficient & $\begin{array}{l}\text { McFadden } \\
\text { R-squared }\end{array}$ \\
\hline \multirow{8}{*}{$\begin{array}{l}\text { Model } \\
1\end{array}$} & AGE & $-0.010325^{2}$ & \multirow[t]{8}{*}{0.085448} \\
\hline & BEAUTY_INDEX & $\begin{array}{l}2.294191 \text { *** } \\
( \pm 0.57)\end{array}$ & \\
\hline & EDUCATION & 0.156223 & \\
\hline & GENDER_MALE & 0.230491 & \\
\hline & MARITAL_MARRIE & -0.522740 & \\
\hline & MARITAL_OTHER & 0.999741 & \\
\hline & YEARS_USING_FB & 0.016515 & \\
\hline & $\mathrm{C}$ & -0.725223 & \\
\hline \multirow{10}{*}{$\begin{array}{l}\text { Model } \\
2\end{array}$} & AGE & -0.028529 & \multirow[t]{10}{*}{0.108556} \\
\hline & MORE_THAN_100_LIKE_FOR_P & 0.123530 & \\
\hline & MORE_THAN_200_FB_FRIENDS & 0.310710 & \\
\hline & MORE_THAN_70_FOLLOWERS & $1.737650 * * *( \pm 0.47)$ & \\
\hline & GENDER_MALE & 0.211678 & \\
\hline & MARITAL_MARRIED & -0.846306 & \\
\hline & MARITAL_OTHER & 0.378813 & \\
\hline & YEARS_USING_FB & 0.006247 & \\
\hline & EDUCATIONAL_STATUS & 0.153556 & \\
\hline & $\mathrm{C}$ & 0.036955 & \\
\hline \multirow{9}{*}{$\begin{array}{l}\text { Model } \\
3\end{array}$} & AGE & -0.048234 & \multirow[t]{9}{*}{0.156175} \\
\hline & BEAUTY_INDEX & $2.437330 * * *( \pm 0.62)$ & \\
\hline & EDUCATION & 0.078225 & \\
\hline & GENDER_MALE & 0.317045 & \\
\hline & MARITAL_MARRIED & -0.253210 & \\
\hline & MARITAL_OTHER & 1.262424 & \\
\hline & YEARS_USING_FB & 0.024938 & \\
\hline & MEMBER_JOB_GRO & $1.433596 * * *( \pm 0.36)$ & \\
\hline & $\mathrm{C}$ & -0.708796 & \\
\hline
\end{tabular}

\footnotetext{
$2_{* * *}$ : significant at $1 \%$

**: significant at $5 \%$

*: significant at $10 \%$
} 
The result shows that a Facebook-user with a higher interval of BI (one interval is 0.33) will have about 9.87 times $\left(\mathrm{OR}=e^{2.29}, \mathrm{p}=0.001\right)$ more probability to get a job on Facebook than their counterparts (Table 1 . On the contrary, other variables show no statistical significance towards an individual's probability of getting jobs on Facebook. The variable "kind of job: temporary or permanent" is left out from the previous model because of the large number of missing values. Similarly to the interviews' result, this result supports that either in case of being employed or self-employed, beauty is strongly assumed with higher marginal productivity, which explains why beautiful people are hired more than their counterparts. Interestingly, when BI is replaced by the number of friends, 'likes' and followers, the R-squared in the logit model increases about 3\% (Table 2). Moreover, the variable "having more than 70 followers" appears to be the most dominant indicator in BI with pvalue of 0.0002 . On the other hand, "having more than 100 'likes' and "having more than 200 friends" variables show no statistical significance. This result shows that those having more than 70 followers on Facebook will have 5.69 times more chances to get jobs on Facebook than those with less than 70 followers $\left(\mathrm{OR}=e^{1.74}, p=\right.$ 0.002). The importance of followers in getting a job on Facebook can be explained through the popularity of the user. Indeed, a person followed by others usually possesses some important characteristics: either of his or her beauty, smartness, or reputation. And together with the average of 200 friends, the number of followers will at least contributes to an individual's possibility of selling products on Facebook. "The more people know about your business, the higher number of customers you will have," as it is always mentioned in the interviews.

Table 2:

\begin{tabular}{|c|c|c|}
\hline \multicolumn{3}{|c|}{ Dependent variable: BEING EMPLOYED ON FACEBOOK } \\
\hline Independent variables & Coefficient & $\begin{array}{l}\text { McFadden R- } \\
\text { squared }\end{array}$ \\
\hline AGE & -0.062357 & \multirow[t]{9}{*}{0.086922} \\
\hline MORE_THAN_100_LI & 0.051933 & \\
\hline MORE_THAN_200_FB_FR & 0.192179 & \\
\hline MORE_THAN_70_FO & $\begin{array}{l}1.288063 * * * \\
( \pm 0.4)\end{array}$ & \\
\hline EDUCATION & $\begin{array}{l}0.480355^{* *} \\
( \pm 0.22)\end{array}$ & \\
\hline GENDER_MALE & 0.019773 & \\
\hline MARITAL_OTHER & -0.630632 & \\
\hline YEARS_USING_FB & 0.058079 & \\
\hline $\mathrm{C}$ & -0.990132 & \\
\hline
\end{tabular}

The dominance of the variable "having more than 70 followers" is also obvious when "being employed" (1) and "being self-employed" (2) are considered as dependent variables respectively. Besides the variable "having more than 70 followers," educational status also significantly affects the probability of an individual's being employed on Facebook (Table 2). This is because most of the participants are university-level, who are the most active users on Facebook as well as in need of part-time jobs. The result shows that a user with a higher level of education (for instance, from high school to college) are about twice more likely to being employed than others $\left(O R=e^{0.48}, p=0.03\right)$. It is vital to note that the marital status variable is left out in this regression because of its quasi-complete separation problem. In other words, all of married respondents in the sample are not employed on Facebook.

When being self-employed is taken as a dependent variable, the predicted model is:

$\operatorname{logit}(\pi)=-2.07+0.8^{*}$ (having more than 70 followers on FB $)+0.26 *$ (years using FB)

The model indicates that when other variables remain constant, "having more than 70 followers" increases the chance of a Facebook user's being self-employed by 2.23 times. Furthermore, the variable "years of using Facebook" also significantly contributes to the probability of an individual becoming self-employed. When other variables remain constant, with one more year of using Facebook, an individual's possibility of selling online products will increase by 1.29 times $\left(O R=e^{0.26}, p=0.03\right)$. This explains the importance of networks: using Facebook for a longer period is positively associated with the number of friends, customers and information in selling products' process.

Table 3:

\begin{tabular}{|l|l|l|}
\hline Dependent variable: BEING SELF-EMPLOYED ON FACEBOOK \\
\cline { 1 - 2 } Independent variables & Coefficient & $\begin{array}{l}\text { McFadden R- } \\
\text { squared }\end{array}$ \\
\hline AGE & -0.014302 & 0.067083 \\
MORE_THAN_100_LI & 0.296026 & \\
\hline MORE_THAN_200_FB_FR & 0.500642 & \\
\hline
\end{tabular}




\begin{tabular}{|l|l|}
\hline MORE_THAN_70_FO & $\begin{array}{l}0.801523 * * \\
( \pm 0.32)\end{array}$ \\
\hline EDUCATION & -0.061633 \\
\hline GENDER_MALE & 0.118539 \\
\hline MARITAL_MARRIED & 0.569156 \\
\hline MARITAL_OTHER & 0.028285 \\
\hline & $0.256918 * *$ \\
YEARS_USING_FB & $( \pm 0.11)$ \\
\hline C & -2.071777 \\
\hline
\end{tabular}

Unexpectedly, an individual's membership of any job-searching group significantly influences the probability of an individual getting a job on Facebook. When membership of job-groups is included in the base model, R-squared value increases from $8 \%$ to about $16 \%$, and F-value shows more significance than previous models. The rapid increase in R-square value (about 100\%) is likely to emphasize the vital contribution of being members in job-groups to get jobs on Facebook (Table 6). In fact, members of any job-searching group have 4.18 times $\left(O R=e^{1.43}, p=0.0001\right)$ more likely to get jobs than those who are not. This is because being members of these groups expands individuals' networks and information range and in turn reduces their frictional unemployment.

\section{CONCLUSION}

This paper targets to answer what personal characteristics and Facebook's features affecting unemployment level among the Vietnamese youth. These results show that the membership of job-searching groups significantly influences the possibility of being employed or becoming self-employed on Facebook. Furthermore, Beauty Index, especially the number of followers on Facebook, is also positively correlated to one's chance of getting jobs on Facebook. With this, it tends to shift the question of how to discourage people to spend lots of time on Facebook into how to use Facebook effectively. This is because ultimately Facebook is another tool of job searching, and it is likely to reduce unemployment among Vietnamese youth if used efficiently.

However due to time and budget constraints, and especially the nature of collecting data on the Internet where the researcher has no mean to testify the validity and completeness of answers of surveys, the number of missing values in this study is numerous. Furthermore, ambiguity in defining jobs is an obstacle in getting proper response. Also, together with the lack of a bigger sample size, the study seems to miss out some important factor such as experiences, the intensity of job-hunting and prior working experiences, all of which influence the probability of one's getting jobs on Facebook. This explains the low value of McFadden R-squared in models. What's more, the snow-ball and convenient sampling may also lead to response and voluntary biases. Hence, the findings and hence, suggestions of this study should be considered with much caution.

\section{REFERENCES}

[1] Asia Marketing Research, Internet Usage, Population Statistics and Facebook Information. Internet World Statswebsite: http://www.internetworldstats.com/stats3.htm

[2] Autor, David H (2001). Wiring the Labor Market.nber.org. Journal of Economic Perspectives: page 2540 .

[3] Cooper, Belle Beth.7 Powerful Facebook Statistics You Should Know About. fastcompany.comwebsite: http://www.fastcompany.com/3022301/work-smart/7-powerful-facebook-statistics-you-should-knowabout

[4] Facebook Reports Fourth Quarter and Full Year 2014 Results. investor.fb.comwebsite: http://investor.fb.com/releasedetail.cfm?ReleaseID=893395

[5] Frey, Carl Benedikt and Michael A. Osborne (2013). The Future of Employment: How Susceptible Are Jobs to Computerization? OxFord Martin School.

[6] Kelly, Heather. By the Numbers: 10 Years of Facebook.cnn.com. Tech-Social Media, 4 Feb. 2014. Web. 30 Sept. 2014.

[7] Khanh, Tan Vu Ngo, Gwangyong Gim. Factors Affecting the Online Shopping Behavior: An Empirical Investigation in Vietnam. Journal of Engineering Research and Applications 4.2 (2014): 388-93.

[8] Kramer et al, Adam (2014). Experimental Evidence of Massive-Scale Emotional Contagion through Social Networks.pnas.org, 111 (29), 8788-90.

[9] Kroft, Kory and Devin G. Pope (2014).Traditional Search and Improve Matching Efficiency? Evidence from Craigslist. Jstor.org. Chicago Journal, 32 (2), 259-303.

[10] Kuhn, Peter (2014). The Internet as a Labor Market Matchmaker. Econpapers.repec.org. IZA World of Labor: page 1-10. 
[11] Kuhn, Peter and Hani Mansour. Is Internet Job Search Still Ineffective? Wiley Online Library. The Economic Journal, DOI: 10.1111/ecoj.12119.

[12] Kuhn, Peter J. (2003). The Internet and Matching in Labor Markets. New Economy Handbook: page 1-13.

[13] Kuhn, Peter, and Mikal Skuterud (2004). Internet Job Search and Unemployment Durations. American Economic Review, 94(1): 218-232.

[14] Leiner, Barry M. Brief History of the Internet. Internetsociety.orgwebsite: http://www.internetsociety.org/internet/what-internet/history-internet/brief-history-internet

[15] Mang, Constantin (2012). Online Job Search and Matching Quality. Econpapers.repec.org. Ifo Working Paper No. 147: page 1-34.

[16] Monsuwe, TonitaPerrea y et a. (2004). What Drives Consumers to Shop Online? A Literature Review? Emerald Group Publishing Limited. International Journal of Service Industry Management, 15 (1): 10221.

[17] Ngan Anh. Online Shopping Gathers Momentum in Vietnam.TN News website: http://www.thanhniennews.com/business/online-shopping-gathers-momentum-in-vietnam-39427.html

[18] Prompongsatorn, Chanidapa et al. (2012). The Factors Influencing Consumer Trust of Internet Shopping in Thailand.asbbs.org, 19 (1): 736-45.

[19] Sedghi, Ami. Facebook: 10 years of social networking, in numbers. The Guardian.Datablogwebsite: http://www.theguardian.com/news/datablog/2014/feb/04/facebook-in-numbers-statistics

[20] Stevenson, Betsey (2006). The Impact of the Internet on Worker Flows.kellogg.northwestern.edu: page 124.

[21] Stevenson, Betsey (2009). The Internet and Job Search. National Bureau of Economic Research, Inc. Studies of Labor Market Intermediation: pages 67-86.

[22] The Top 20 Valuable Facebook Statistics - Updated February 2015. zephoria.comwebsite: https://zephoria.com/top-15-valuable-facebook-statistics/

[23] Vojvodic, Katija and MateaMatic (2012).Online Purchasing Intentions of Croatian Customers.scientificpapers.org. Journal of Knowledge Management, Economics and Information Technology, (6): 1-12. 